\title{
BLIVER COVID-19 EN DEL AF DEN KOLLEKTIVE ERINDRING?
}

AT GLEMME DEN SPANSKE SYGE 1918/19

Hvordan har kollektiv erindring formet vores oplevelse af coronapandemien? Og hvordan kommer vi til at huske covid-19 i fremtiden? Dette er spørgsmål, der drøftes i det tværfaglige felt af kulturelle erindringsstudier.

Vi kunne have set det komme! Mere end to dusin epidemier og pandemier er skyllet ind over kloden i løbet af de sidste hundrede år (heriblandt SARS, MERS, svineinfluenzaen og HIV/AIDS). Den værste pandemi var den spanske syge i 1918/1919, som ifølge nylige skøn dræbte mellem 50 og 100 millioner mennesker - mere end Første og Anden Verdenskrig tilsammen.

Men på trods af hundredårsjubilæet for et par år siden har den spanske syge aldrig tilhørt, hvad historikeren Reinhart Koselleck har betegnet som et "oplevelsesrum". Den er ikke en del af vores kollektive erindring - den bliver ikke mindet bredt, ikke omtalt i skolen, er ikke fokus for berømte romaner eller ikoniske malerier. Den har derfor ikke kunnet forme vores "forventningshorisont".

Vi kunne have set det komme, men de fleste mennesker i Europa blev totalt overraskede over COVID-19 og de alvorlige foranstaltninger, der skulle tages i marts og april 2020 for at kontrollere virussens spredning. Vores 
oldefædre, i 1918, havde allerede gennemlevet social distancering, midlertidige felthospitaler, brugen af ansigtsmasker og endda fodboldkampe uden tilskuere. Men disse oplevelser forblev uerindrede.

\section{KOLLEKTIV ERINDRING I CORONAKRISEN}

Men hvad huskes i øjeblikket? Hvilke kollektive erindringer udløses og anvendes til at indramme pandemien? Det lader til, at den kolde krigs tankemønstre (rygter om biologiske våben), racemæssige stereotyper (angreb på asiatiske mennesker, genoplivning af antisemitisme) og nationale minder fra Anden Verdenskrig (Trump sammenligner coviD-19 med Pearl Harbor) genoplives. I mange lande genopliver lockdowns minder om udgangsforbud under diktaturer.

Et lille lyspunkt: folk begynder at genlæse bøger om fortidens pandemier, fra Boccaccios Decameron (ca. 1349-53) til Camus' Pesten (1947). På denne måde bliver også den spanske syge forvandlet fra en rest i det støvede arkiv til en del af den aktive, udbredte og levende hukommelse. Bøger som Laura Spinneys autoritative verdenshistorie om den spanske syge (Pale Rider, 2018) er pludselig udsolgt.

\section{FREMTIDENS MINDER OM COVID-19}

Hvis pandemier ikke har spillet en stor rolle i den hidtidige kollektive hukommelse, hvordan vil fremtiden så huske den nuværende coronakrise? Det er der selvfølgelig ingen der ved, og alt hvad jeg skriver nu, er ren formodning, endda før de historiske begivenheder er afsluttede.

Men et par ting er bemærkelsesværdige: coviD-19 er den første globale pandemi i den digitale tidsalder. I forhold til arkiver (inklusive verdensomspændende digital information om sagsnumre og cirkulation af personlige oplevelser via sociale medier) vil der være en overflod af kilder til fremtidig kollektiv erindring.

Meget kollektiv erindring afhænger af top-down processer: Vil nationalstater eller EU "investere" i minder om coronapandemien? Vil de oprette mindehøjtideligheder, mindedage eller endog museer? Bliver pandemien 
skrevet ind i historiebøger? Dette vil sandsynligvis være tilfældet i lande, der er blevet hårdt ramt. Men problemet med at huske sundhedskriser og naturkatastrofer er, at de menneskelige handlinger i dem er mindre tydelige end i f.eks. krige, folkedrab og terrorangreb. Det er derfor vanskeligere at udlede normative lektioner fra pandemier: Hvem er ansvarlig for CoviD-19? Hvordan kan man formulere et 'aldrig mere'?

\section{EN CORONA-GENERATION?}

Men der er også bottom-up-processer i forhold til kollektiv hukommelse. Den ene er generationshukommelsen. Coronapandemien har alle ingredienserne til en generationsdefinerende oplevelse. For de unge, der nu er i hvad sociologen Karl Mannheim har kaldt deres "formative år" (ca. 17-24 år) betyder de nuværende lockdowns både udvidede (i betragtning af at tiden flyder langsommere, når man er ung) og fundamentale ændringer: Skole, universitet, socialt samvær og ja, dating, såvel som overgangsritualer (fra eksamensfester til udlandsrejser) er ikke, hvad de plejede at være.

Samtidig er denne generation vidne til både den akutte globale risiko og en hidtil uset grad af verdensomspændende forbundethed. Dette er en betydningsfuld erfaring. Begivenheder i ungdomsårene og den tidlige voksenalder huskes bedst i hele levetiden. De har også tendens til at forme en persons politiske ideer. COVID-19 kan i de unges erindringer blive forbundet med den aktuelle Fridays for Future-bevægelse. I så fald ville den generationelle hukommelse kunne fastholde en følelse af at være eksistentielt vævet sammen med en global dynamik af klimaændringer, udryddelse af arter og pandemier - og behovet for kollektiv handling.

Men dette er et håbefuldt scenarie. Erindringen om coronakrisen kan også blive helt blokeret eller overskrevet af efterfølgende økonomiske eller politiske kriser. Og selvfølgelig vil kollektiv erindring antage forskellige former afhængigt af om pandemien blev oplevet fra et sted med få eller mange coronaofre, i autokratiske regimer, i svigtende eller vellykkede demokratier, fra toppen eller bunden af det globale samfund. 
38 KULTUR \& KLASSE * $131 * 2021$ SYGDOM

Artiklen blev oprindeligt udgivet i Manuela Gerlof og Rabea Rittgerodt (red.): 13 Perspectives on the pandemic Thinking in a state of exception (Walter de Gruyter, 2020), under titlen "Will Covid-19 Become Part of Collective Memory?" og er oversat af Karen Hvidtfeldt og Per Krogh Hansen med tilladelse af forfatter, redaktører og forlag.

Astrid Erll er professor i engelsk og initiativtager til Frankfurt Memory Studies Platform ved Goethe Universität Frankfurt am Main. Hun er også medredaktør for De Gruyter-serien Media- and Cultural Memory. 